\title{
Contemporary Quests and Struggles of Small-Scale Family Farms toward Sustainable Agriculture in Thailand
}

\author{
Yuichiro Amekawa ${ }^{1}$ \\ ${ }^{1}$ Faculty of Agriculture, Kyushu University, Fukuoka, Japan \\ Correspondence: Yuichiro Amekawa, \#111 Building 7, 6-10-1 Hakozaki, Higashi-ku, Fukuoka 812-8581, Japan. \\ Tel: 81-92-642-7178. E-mail: yamiko7@hotmail.com
}

Received: February 29, 2016

doi:10.5539/ass.v12n5p1
Accepted: March 10, 2016 Online Published: April 19, 2016

URL: http://dx.doi.org/10.5539/ass.v12n5p1

\begin{abstract}
One of the pillars of Thai Studies is to examine Thai rural society and culture, especially that of small-scale farmers who comprise the majority of rural agriculturalists in Thailand. The purpose of this paper is to highlight the characteristics and challenges of contemporary Thai rural society through elucidating the pursuit and struggles of small-scale family farms toward 'sustainable agriculture' in the context of deepening social and environmental challenges associated with modern industrial agriculture. For this objective, an overview is presented with regard to the characteristics of small-scale family agriculture in Thailand, followed by accounts of the contemporary circumstances of integrated farming, organic farming, and public good agricultural practices in which small-scale family farms have been involved.
\end{abstract}

Keywords: sustainable agriculture, small-scale family farms, integrated farming, organic farming, good agricultural practices, Thailand

\section{Introduction}

Maruyama (1996) argued that the substratum of Thai culture in the rapidly transforming Thai society lies in rural culture. Likewise, one of the pillars of Thai studies is to study Thai rural society and culture, especially that of small-scale family farms. In Thailand, modernization has been accelerated since the first National Economic Development Plan (1961-1966) was launched under the then prime minister Sarit Thanarat in 1961. From the mid-1980s in particular, industrialization was promoted via the boom of foreign investment, and the country is now regarded as a middle-income country where a mass consumption society has emerged.

Nonetheless, even at present much of the national land of the country is of rural nature. According to the labor survey of 2012, farming population in Thailand is 1,635 million, accounting for 41 percent of the total working population. The number of farms across the country in 2009 is 5.78 million, of which 2.69 million lives in the Northeast, accounting for 46.5 percent nationwide. Actual cultivation area per farm household in Thailand is 3.6 ha (Inoue, 2012), and the majority of farmers are family-based, small-scale self-managed farms (Jitsanguan, 2001).

In rural Thailand, Green Revolution technologies were introduced in the 1970s and widely disseminated in the 1980s. The Green Revolution refers to innovations in multiple layers of agricultural production: 1. the improvement and dissemination of new high-yielding varieties (HYVs) (plant genetic innovation); 2. the establishment of irrigation and drainage facilities, and field infrastructure (engineering innovation); 3. the introduction of intensive farming techniques (management innovation); and 4. institutional enhancement such as the diffusion of new cultivars, the distribution of inputs, and the collection of produce (administrative innovation). The Green Revolution has given rise to a productivity revolution which transcends the ability of traditional rice farm management systems in many countries of East and South Asia. In Thailand too, rice production has increased in a relatively short period from 2.8 tons per ha (rice hull in 1965) to 3.8 tons per ha (yet only during the dry season in 1980) through the Green Revolution (Kitahara, 1985).

A series of social problems has followed the introduction of Green Revolution technologies in Thailand, however, including a decrease in prices of agricultural produce due to supply surplus, an increase in farm production costs and associated debts of farm households, pest resistance against synthetic pesticides, health problems due to exposure to pesticides (Note 1), environmental pollution due to the use of various agrochemicals, among others 
(Kan'no, 2008; Suksuri et al., 2008). Owners of a large farmland were capable of utilizing the new capital investments comprehensively and efficiently, with the sales from the harvest greatly exceeding the costs incurred. Among those who could not make such investments were small-scale farmers whose profitability went downhill despite their increased production (Kitahara, 1990).

In the context of deepening social and environmental problems associated with modern industrial agriculture, small-scale farmers began to adopt alternative agriculture from the early 1980s, supported by non-governmental organizations (NGOs), consumers, and environmentalists for its diffusion in rural areas and the establishment of specialty markets in urban areas (Kan'no, 2008). With this development of agroecological movement and the rise of a notion of agriculture called "New Theory" proposed by the highly respected King of Thailand Bhumibol Adulyadej (Rama IX) in 1993 (Suksuri et al., 2008), the government began to actively promote policies for 'sustainable agriculture' from the late 1990s (Amekawa, 2010). Albeit with the conceptual vagueness, sustainable agriculture was defined in the official development plan as relevant to four types of agricultural practices in Thailand including natural farming, organic farming, integrated farming (of which New Theory Farming is part) and agro-forestry (National Economic and Social Development Board, 1997).

A growing body of academic studies has examined sustainable agriculture in Thailand. Jitsanguan (2001) contends that sustainable agriculture is viable both economically and ecologically for small-scale farmers in Thailand, which justifies the need for carrying out supportive policies for sustainable agriculture in the nation. Buch-Hansen (2001) presented a feasibility analysis of the political and institutional development of sustainable agriculture in Thailand. He argued that the lack of the financial capability of Thai government would make it difficult to provide support for both commercial and less competitive farmers in converting to sustainable agriculture either through trade or non-trade related measures. It is worth noting that these analyses were conducted at the time when the official sustainable agricultural programs were not instituted very much yet. Nearly a decade later, Amekawa (2010) examined the feasibility of official institutional programs for sustainable agriculture in Thailand. By empirically analyzing the cases of three official programs promoting organic agriculture and the reduced use of agrochemicals, he concluded that the achievements in the past decade were still limited for the estimated 5 million small-scale farms in Thailand. Reviewing a series of policy portfolios and outcomes for promoting conventional and sustainable agriculture in Thailand, Kasem and Thapa (2012) shared the similar conclusions with Amekawa, arguing that the lingering structure of the conventional agricultural regime is inhibiting the growth of the sustainable agriculture sector in Thailand. In a wider historical and regional spectrum, official efforts for sustainable agriculture in Thailand have not been instituted more systematically than the case of Indonesia for example, where by 1994 300,000 rice farmers had been successfully trained by the government and the Food and Agriculture Organization (FAO) to practice integrated pest management (IPM) through farmer field schools (FFS) and other measures (Röling and van de Fliert, 1994). Nonetheless, Thailand has public standards for organic agriculture, enforces pesticide regulation relatively well, while monitoring conditions on pesticide imports (Schreinemachers et al., 2015). The overall social and institutional conditions appear to be more positive in Thailand than several lower income countries in Southeast Asia currently in a transition to the modern agricultural development regime. In Cambodia and Laos for instance, pesticide labels are often written in foreign languages such as Thai and Vietnamese, and farmers' high illiteracy rates and low educational levels result in the misuse of pesticides (Gallagher et al., 2005).

This paper aims to highlight the characteristics and challenges of contemporary Thai rural society through elucidating quests and struggles of small-scale family farms who intend to find a way out to sustainable agriculture. As shown above, overall, the existing studies are not very positive of the extent to which official promotion for sustainable agriculture has been realized in Thailand. Yet they lack a specific, subsector-based explication such as integrated farming, New Theory Farming, and social movement components of organic farming. An overall evaluation of the public policy of good agricultural practices in Thailand has been outmoded as well, with the absence of international comparative perspectives. Further, small-scale family farming in Thailand has not been well defined in contextual terms when it is held relevant to sustainable agriculture. The present paper intends to fill these gaps.

The rest of the paper is devoted to an overview of small-scale family agriculture in Thailand, quests and struggles of small-scale family farms toward sustainable agriculture as it relates to integrated farming, organic farming and good agricultural practices, closed with conclusions.

\section{Small-Scale Family Agriculture in Thailand}

In examining small-scale family farm issues, a question arises as to how much scale of farm management is considered 'small-scale.' The Land Reform Office of Thailand (ALRO) defines a small-scale farm as managing 
the land of 10-20 rai (1.6-3.2 ha) (Hirokawa, 2010). Thai Development Research Institute defines it as managing 15 rai $(2.4 \mathrm{ha})$ or less (Watanabe, 2008). In some areas, it may be regarded as appropriate to define a small-scale farm as managing 10 rai (1.6 ha) or less (Kitahara, 2005). There are no established international criteria to define a small-scale farm but international organizations such as the World Bank, the Africa Development Bank, and the Consultative Group to Assist the Poor (CGPA), generally define a small-scale farm in developing countries as 2 ha or less (Calcaterra, 2013). Given that the average land management size in Thailand is 3.2 ha (Inoue, 2012), here we partially adopt the ALRO's official definition of a small-scale farm in Thailand and assume it as the management scale of 20 rai (3.2 ha) or less.

Next, what are the characteristics of small-scale family farming in Thailand? To consider this question, it is necessary to consider the traditional structure of family and its changes in contemporary Thailand, as we as their relationships with agriculture, in particular rice farming.

Table 1. Changes in the Family Structure in Thailand

\begin{tabular}{lrrr}
\hline Year & 1980 & 1990 & 2000 \\
\hline Nuclear family (\%) & 73.7 & 72.0 & 67.0 \\
Stem family & 24.9 & 26.2 & 26.6 \\
Other family & 1.4 & 1.8 & 6.4 \\
\hline
\end{tabular}

Source: English translation of Takeuchi (2015)

Note. No data after 2000 are available due to the lack of data collection from that year on family structure in Thailand.

As Table 1 shows, nuclear family was on decline in the two decades from 1980 to 2000. This trend suggests a contrast to the case of developed countries where the proportion of nuclear family has been on the rise. In addition, stem family remained at approximately the same level while 'other family' has rapidly increased from 1990 to 2000. Other family here refers to the integrated family that exhibits the most complicated family structure. In concrete terms, it refers to nuclear family of siblings (joint family) or family of parents and siblings (stem family or joint family) where the members share a residence. According to Takao Takeuchi, a leading Japanese researcher on Thai family, integrated family comprises the basic layer of Thai family structure. It is deep-rooted in the local community as a meta-family that reproduces forms of family being classified on statistics as nuclear family or stem family (Takeuchi, 2010). As a special overarching form of family peculiar to Thai family, Koichi Mizuno (1981) once called it "multihousehold compound."

This concept refers to the attachment of parent and child within a household family, as shown below. First, marriage of a child is matrilocal. If there is more than one daughter, after marriage each of them lives with parents for a while in the order of marriage. The case where a daughter's household lives with her parents is designated as stem family while the case where two or more daughters' households live with their parents is termed as joint family. As time goes by, daughters' households leave parents' home in the order that they had entered it. Finally, the youngest daughter (or the youngest son where there is no daughter) continues to live with parents after marriage and takes care of them. After finishing the period of living together with their parents, children who have separated households continue to maintain cooperation with their parents and sisters in agricultural production and consumption activities, given that the parents control their farmland (especially rice paddies) until they pass away. Therefore, the household of a daughter' couple is not a completely independent unit even after they stopped living together with her parents (Takeuchi, 2009).

The basic structure of a multihousehold compound has been shared nationally even though there are regional and local differences in the extent of daughters living together with their parents (Takeuchi, 2010). The farm household economy in Thailand has rapidly been dependent on off-farm incomes along with accelerated industrialization since the mid-1980s, however. Accordingly, forms of farm household and management within the multihousehold compound have altered to a significant degree. Such changes are characterized as individualization and a decline of cooperation in agricultural production and household consumption. For instance, exchange in agricultural labor has disappeared following the development of the mechanization and commercialization of agriculture. As wage laborization in rice cultivation has progressed, cooperation between parent and child in rice planting and harvest has dissipated. It has become more common instead that parent and child employ wage labor respectively and manage the paddy individually while adding family workforce 
adjunctively (Takeuchi, 2012). In addition, the sense of cooperation in the family has altered due to the progress of part-time farming and de-agriculturalization associated with the increase in off-farm labor.

In rural Thailand, industrialization has not progressed nor has its labor market been developed very much. Nonetheless, farmers living in such areas have had to be more dependent on off-farm work. This is related to the need for covering the mounting cost in agricultural production such as the purchase of chemical fertilizer and pesticides. A daughter and her husband, who are living with her parents, has been increasingly involved in migrant labor to distant places such as Bangkok or provincial cities in search of better off-farm income opportunities. Accordingly, it has become common that parents work on the farm full-time while children engage in part-time farming (Takeuchi, 2009). In case a daughter is a married woman with a child or more, she may have some of her family members (especially mother) take care of her children remaining in the village during her leave for migrant work. As long as her parents still stay healthy, her remittance to her home in the village tends to be devoted mainly to supporting her children. This situation seems to be a world away from what it once was when daughters' migration was limited to the period before marriage and its purpose focused on remittance for filial piety (Takeuchi, 2015). Further, even where a daughter lives with her parents, the individualization of household consumption has been in progress due to the development of individual ownership and the use of electrical appliances within a household (Takeuchi, 2009). Moreover, as the decline of birth rate and the engagement in higher education have proceeded and as the child generation has come to engage in off-farm labor, it has been increasingly seen that the children (especially adult men) living together with their parents are weary of doing agricultural work. They do not work on the farm even if parents tell them to do so. More parents have also become less willing for their children to work on the farm too. Therefore, many children at the age when they can do farming no longer give a help to parents for rice farming (Takeuchi, 2012).

At the root where parents and children have maintained cooperation to each other in multihousehold compound is a sense of reciprocity with which parents maintain their farmland and lend part of it to their children until they die while their children in return take care of them. The recent progress of part-time farming and de-agriculturalization, coupled with the progress of the declining birthrate and aging, act in the direction to weaken this reciprocal relationship. Hence, small-scale family farming in Thailand seems to enhance the tendency that as a livelihood strategy in the mass consumption society children depend selectively and supplementarily on their parents and agriculture as needed while their parents are obliged to respond to it.

\section{Quests and Struggles of Small-Scale Family Farms toward Sustainable Agriculture}

The origin of the sustainable agriculture movement in Thailand dates back to the 1980s. To deal with the problems arising from the modernization of agriculture, farmers, NGOs, consumers, and environmentalists established the 'Alternative Agriculture Network' in 1989 as a coalition for bundling multiple NGOs to promote sustainable agriculture. Derived from the Network, the Green Net began its business in 1993 as the first retail group in Thailand who deals with organic agricultural produce (Ōuchi, 2004, Kan'no, 2008). In the field of economic policy, on the other hand, policy interests in sustainable agriculture were expressed in the 7th National Social and Economic Development Plan (1992-96) for the first time. In the subsequent 8th Plan (1997-2001), sustainable agriculture was raised as a policy issue for the first time with the goal of converting $20 \%$ of farms to sustainable agricultural practices related to natural farming, organic farming, integrated farming, and agroforestry (Panyakul, 2001). Subsequently under the Thaksin administration, which upheld a strong export promotion policy, a public policy framework of good agricultural practices (GAP) for ensuring food safety in export markets was introduced in 2004. This introduction meant an extension of the meaning of sustainable agriculture such as agricultural practices that lead to a reduction in or an optimization of the use of pesticides and chemical fertilizer through IPM and crop diversification (Amekawa, 2010).

In the following, an overview is presented with regard to the contemporary circumstances of integrated farming, organic farming, and GAP in which small-scale family farms in Thailand are engaged.

\subsection{Integrated Farming}

After experiencing the unprecedented economic boom which was accelerated from 1988, Thailand became the epicenter of the Asian Financial Crisis in 1997. This crisis gave a serious blow to the national economy of each Asian country with the exception of Hong Kong. Thailand has received rescue loans from the International Monetary Fund (IMF), the World Bank, and the Japanese government, with the total amount of US\$17.2 billion (Suehiro, 2009). To Thai people who are struck by the negative outcomes brought about through globalization, the King of Thailand Bhumibol Adulyadej, popularly called the 'King of Development,' presented the ideal future path of the Thai economy as 'Sufficiency Economy.' (Note 2)

This Buddhist-based economic thought embraces a critical view of adhesion to the pursuit of wealth based on the 
externally dependent economic growth and instead emphasizes the importance of 'middle path.' The philosophy was upheld in the 9th National Economic and Social Development Plan (2002-2006) as the central notion of sustainable social development along with 'human-centered development.' It was taken over in the 10th Plan that was formulated after the coup of 2006. The King has also advocated the 'New Theory Farming,' a notion of agriculture emanated from the philosophy of Sufficiency Economy. His promulgation of the notion predates the Asian Economic Crisis, and based on it the Royal Development Projects Board has promoted the dissemination of small-scale integrated farming systems as a stepwise development strategy since 1995 (Note 3).

The New Theory Farming assumes three stages of development. The first stage refers to the self-reliance of the family level through the adoption of integrated farming. With the assumption of a typical smallholder household owning the land of 15 rai (2.4 ha) with 4-5 family members, the farmland is divided with the ratio of 3:3: 3: 1 for rice farming for subsistence, the cultivation of vegetables and fruits, a pond with the depth of 4 meters for aquaculture and irrigation, and housing and livestock, respectively. This stage assumes that through practicing integrated farming, many farmers become able to supply many necessities on the self-sufficient basis. The second stage refers to the self-reliance at the community level through the establishment of farmers' groups and cooperatives. The third and final stage involves a collaboration with agencies outside the community through the development of a network with banks, private companies, retailers, and stores. It is held that by proceeding with such a stepwise self-reliance, farmers can develop their own capabilities and enhance their immunity against external shocks, hence sustainable agriculture being realized (Inoue, 2010; Mori'izumi et al., 2008; Tsumura, 2014).

In rural Thailand, there would be few farmers who have not heard of the New Theory Farming advocated by the King. It is not clear, however, how many farms throughout the country actually practice integrated farming based on the theory. Further, there are quite a few villages in Northeast Thailand where local practical farmers, NGOs, and development monks voluntarily engage in the dissemination of integrated farming through trials and errors (Tsumura, 2014). Renowned cases include the Buddhist development by the abbot Naan in Surin Province (Wongkul, 1993), the case of the village head Mr. Paay in Buri Ram Province (Phongphit, 2009), and the case of the farming group called Inpeng in Sakon Nakhon Province (Satomi, 2009). Such information is fragmental at best, however, and the purview of the movement has not been grasped yet.

In the following, an integrated farming project is highlighted. The project is part of Japan's Overseas Development Aid in Thailand and it has been promoted on a relatively large scale. In 1998, the Thai government requested the Japanese government to develop a program of the vitalization of rural areas after the Economic Crisis. With the conditions of the loaning of Japanese yen, the 'Comprehensive Agricultural Development Program in Land Reform Zones' has been implemented. In this program, integrated farming has been promoted to about 4,000 farm households living in the four provinces of Northeast Thailand including Khon Kaen, Mahasarakam, Sakon Nakhon, and Mukdahan. They have received financial and technical support for the construction of a pond for fish aquaculture and irrigation systems for the cultivation of vegetables, fruits, and rice, as well as for the breeding of livestock and the on-farm recycling of nutrients. A notable feature of this project is related to the organizing of integrated farming groups. When a farmer has a willingness to assist other farmers and his/her farm is rated as well-managed, the farm is designated as a 'study center.' Then the farmer provides a training of integrated farming for farms who have just gained the first pond in their farm, hence a farmer-to-farmer extension. The biggest merit of this method is that farmers under training can see and hear things directly from the instructor farmers who had suffered from the similar situation of indebtedness resulting from monocultural cash cropping. The learners can study how the instructors have converted to integrated farming and improved their life - a merit that cannot be enjoyed from the training offered by government extension officers. The project involves activities of community market (village market for direct sale) which began in 2003. Although self-sufficiency is the highest priority, abundant vegetables and fruits have been harvested through integrated farming using a pond. The villages used to depend heavily on food purchased from external merchants but until now farmers selling their farm products have received more cash income from the community market newly established and carried out once a week by women in the community. Local consumers have also enjoyed buying fresh local organic food at the community market (Oda, 2009).

In this way, this project resulted in multi-functional benefits of integrated farming for many small-scale family farms. It was based on the development aid of Japanese government for the total amount of 4.8 billion yen, however. In order for small-scale family farms to develop integrated farming on a self-reliant basis and without massive external financial support, they must rely on their own labor and organizing ingenuity in the village. Relying only on those internal inputs would make it difficult for them to cover the costs necessary for the management (especially initial costs for reservoir and irrigation). This constraint seems to be the main limiting 
factor for the spread of integrated farming in rural Thailand.

\subsection{Organic Farming}

According to the Green Net's homepage (2015), the cultivation area of organic agricultural crops in Thailand expanded rapidly from 2001 (Figure 1). During the period from 2006 to 2008, it decreased most likely due to the domestic political turmoil and worsening economic conditions. However, it increased again in 2009, amounting to 34,079 ha in 2010. A similar trend is also seen in production and sale (Figure 2). However, they show a slight increase in 2007 even though organic cultivation area decreased in that year. This situation is probably related to the rise in agricultural prices which were related to the soaring crude oil prices around that time. In 2010 organic production amounted to 47,547 tons and the sale to 1.75 billion Baht. Further, according to Vitoon Panyakul (year unknown) who takes a leading position in the Green Net, the cultivation area for organic farming in 2011 amounted to 35,824 ha, accounting for $0.17 \%$ of the total national cultivated area. In that year, the total number of organic farms was 7,499, accounting for $0.15 \%$ of all the farms existing in the nation. These figures are related to the farms and farmlands that have received organic certification which meets international standards. Excluded are those farms who have not received such a certification but have allegedly engaged in organic farming based on their own standard or criteria. Kan'no (2008) calls this type of cultivation 'B-grade organics.' If this type of farming is accepted as organic farming, there would be significantly more organic farms than the figures shown above.

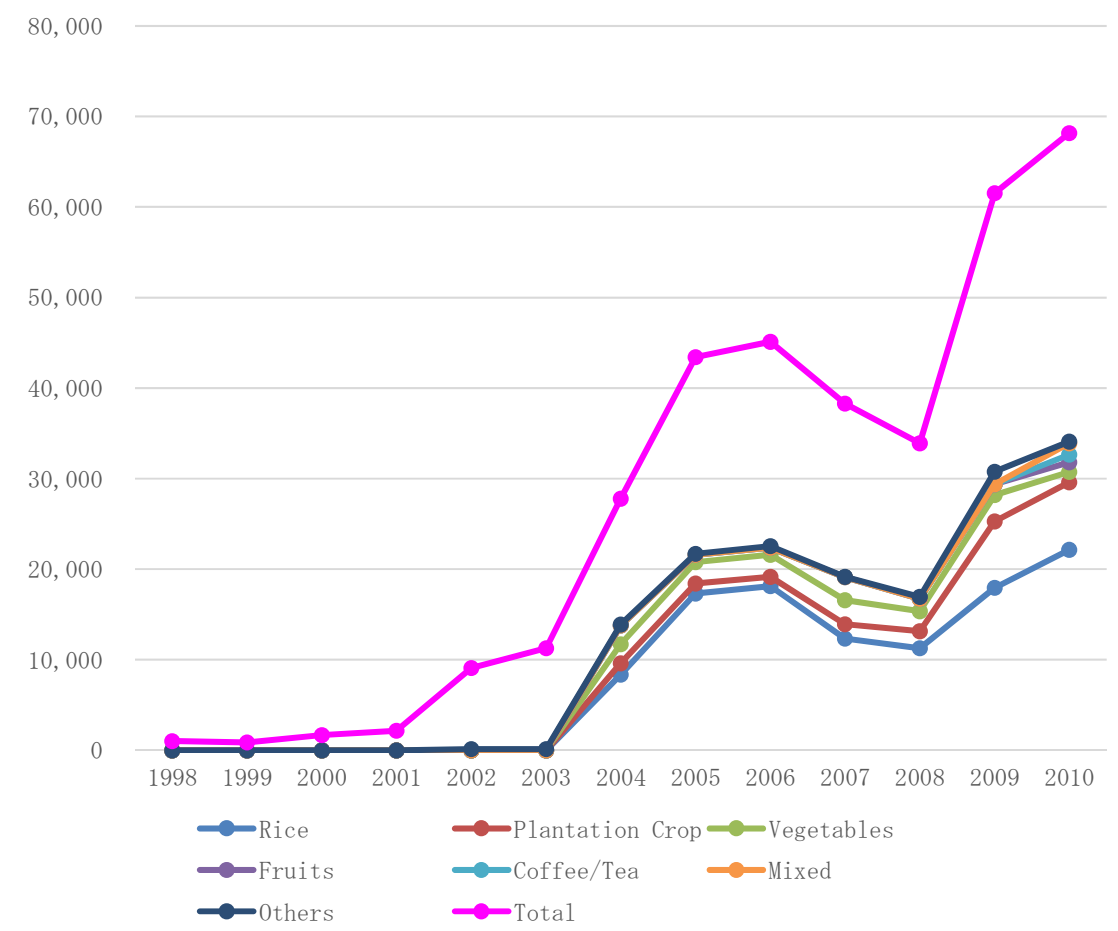

Figure 1. Trends of Organic Cultivation Area in Thailand (ha), $1998 \sim 2010$

Source: created by author based on the table data (rai) in the Green Net homepage (2015)

Note. The data of rice and plantation crops for 1998-2003 are removed from this figure as the data are the sum of those crops rather than for each. For the same reason, the data of vegetables and fruits for 1998-2003 are excluded. 
Production (ton)

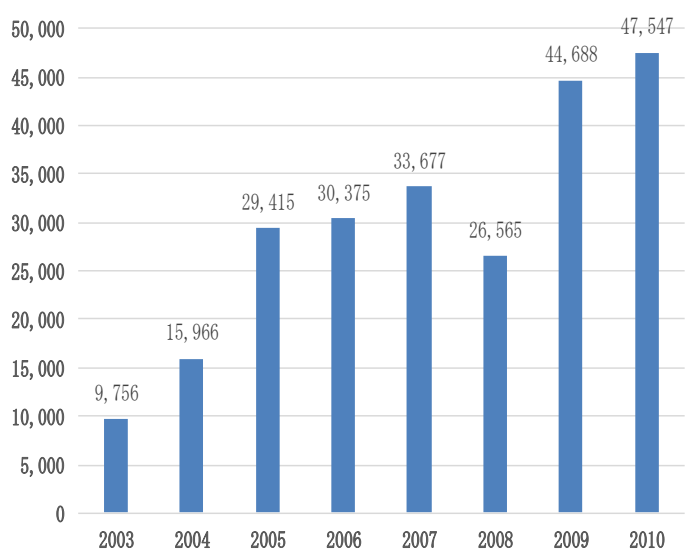

Sales (100 million Baht)

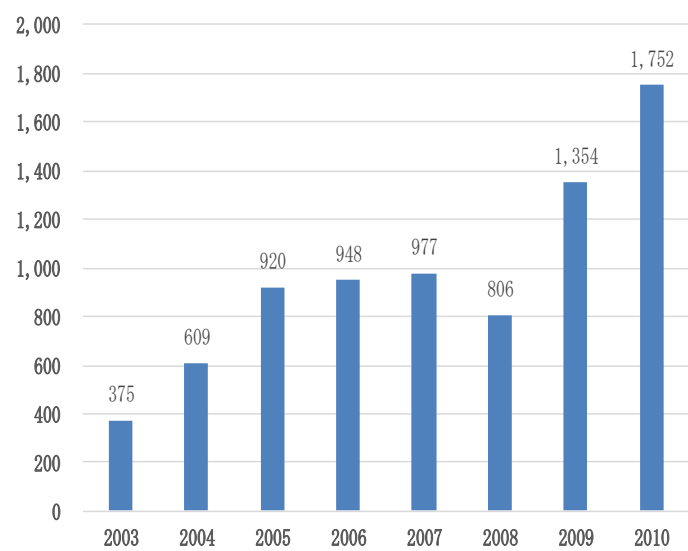

Figure 2. Trends in organic agricultural production and sale in Thailand (2003-2010)

Source: created by author based on the table data in the Green Net homepage (2015).

In the following, an overview of the current situations of organic certification and B-grade organics is presented, followed by the case study of a local organic farming project in Northeast Thailand that exhibits critical relevance to social change in the nation.

The Green Net has played key pioneering roles for the establishment and dissemination of organic certification in Thailand. It established the Alternative Agriculture Certification Thailand (ACT, later renamed the Organic Agriculture Certification Thailand in 1998) as the first domestic private certification agency in 1998. Thanks to this move, a certification system for organic agricultural production, processing, and management operations, commenced in 1995. The ACT became the first organization in Asia that was accredited by the International Federation of Organic Agriculture Movements (IFOAM) in 2002. This made the agency capable of extending their export to the EU markets (Ōuchi, 2004; Kan'no, 2008). With respect to organic certification provided by government agencies, on the other hand, the National Bureau of Agriculture and Food Commodity Standards (ACFS) were established by the Ministry of Agriculture and Agricultural Cooperatives in 2002. The ACFS has been promoting accreditation within the nation since 2004. The ACFS has overseen the regulations of organic farming in Thailand, and the ACT was accredited by the ACFS in 2005. In addition, before the ACT and the government began organic certification, overseas certification authorities began to give certification from the early 1990s to famous organic products such as jasmine rice in Northeast. The example of such authorities are Bioagricert (Italy), Soil Association (United Kingdom), IMO (Switzerland and Germany), OMIC (Japan), Skal (Netherlands), and KRAV (Sweden). The organic produce in Thailand which these certification bodies have certified is exported to EU, primarily the United Kingdom, France and Germany. As regards the farmland of 13,900 ha which received organic certification in 2004, the ACT and the government accounted for $37 \%$ and $13 \%$, respectively, whereas overseas certification bodies accounted for as much as $50 \%$ (Kan'no, 2008).

B-grade organics can be roughly divided into the following two categories. First is the type of organics which farmers have striven to let meet an organic certification standard of international levels but not fulfilled it yet. This type of B-grade organics cannot be distributed in the international market but it may be sold as 'organic agricultural products' at major supermarkets or at fresh food corners of department stores. It is therefore important to provide farmers support for this type of organics in their marketing at domestic markets so that they would not give up organic farming in facing various setbacks. The second type of B-grade organics refers to a generic category that ranges from 'self-styled' organics where farmers bill themselves as doing organic farming to the type of organics promoted by NGOs and producer associations in light of their own criteria and independently of international certification standards (Kan'no, 2008). Farms who engage in this kind of B-grade organics, including those who incorporate it into integrated farming systems, may account for a few percent of the existing farms in Thailand. Many of them have suffered from a large sum of debt and health problems resulting from practicing conventional agriculture over years, thus compelled to aspire conversion to organic 
farming. Many such attempts of conversion have sooner or later ended in vein due to a lack of sufficient financial and policy support. Especially in the first few years of their switch from conventional to organic farming, a volume of production and associated incomes decline drastically due to a reduction in the use of chemical fertilizers and pesticides. Frustrated by the mounting hardship of life, therefore, cases of farms remain rife who give up the conversion before they cultivate the fruits from improvements in the farm environment brought through farming organically. Further, there are cases of the financial breakdown of organic farming projects. In such cases, producer groups tend to have no channels in selling organic produce at major domestic market or overseas markets. They thus attempt to sell organic produce at local markets yet with a lack of any clear differentiation from conventionally grown produce. Accordingly, the prices for organically grown produce are set at the same prices with conventionally grown produce, hence resulting in a deficit and eventually a breakdown of the project. Many of the B-grade organic producers who have been capable of sustainably selling organic sustainably in the local area seem to be those who are in personal contract with schools, clinics, hospitals, or restaurants based on personal reputation or credentials.

Discussed last is an organic farming project that the author observed through intermittent visits from 1998 to 2007 in Chaiyaphum Province, Northeast Thailand. In the late 1980s, some villagers in WY Village of Tambon WT ('tambon' is a subdistrict unit of administration situated between village and district levels), who were interested in ecologically-based local development, contacted a Japanese NGO called the JVC (Japan International Volunteer Center) for collaboration for a community development project. After three years of preparation, they started a small-scale organic vegetable project in 1992. The face-to-face relationship of producers and consumers engaged in direct deals of organic business, often with the consumers playing supportive roles for producers, is called 'sanshō-teikei' in Japan or 'community-supported agriculture' (CSA) in the western world. Participating consumers were of Japanese households living in the condominiums in the Sukhumvit area of Bangkok. Organic produce was given prices fixed throughout the year for each crop in order to complement the average yields that are lower than those obtained through conventional agriculture. The prices, according to the author's survey in 1998, accounted for 2.5 times higher than the regular local market prices for the 23 varieties of vegetable crops grown. In addition, the consumers visit the area of the producers once or twice a year to increase their knowledge and understanding of local issues of organic production as well as develop a solidarity with the producers (Amekawa, 2010).

This project faced the first turning point in early 1996. By that time, the number of growers under contract had increased up to approximately 50 growers selling to more or less 100 consumer households in Bangkok. Since no special regulations over growers' entry had been made by that time, oversupply occurred against the demand. Accordingly, the share of each producer was diminished and so a number of participant farmers were faced with a lack of incomes, resulting in the business breakdown and the withdrawal of the JVC. Following the crisis, farmer representatives made request to the government for financial support for the resumption of the organic project, which was approved subsequently. The project resumed as of state agricultural cooperative in April 1996. In this new system, a new policy to balance supply and demand was hammered out by means of regulating the entry of new grower members in January and February when production is at its annual peak (Note 4) (Amekawa, 2010).

After the enactment of the 1997 Constitution, a national policy to promote rural development was laid as part of the democratization of the government and the decentralization of administration. In the policy, the village council at tambon plays a leading role to develop rural villages. In 1999 the chairman of the organic vegetable project, himself an organic farmer, was selected through election as the first chairman of Tambon WT. With the objectives to spread organic farming within the tambon, as well as to realize the increase of tax revenues in the tambon through activating the local economy, he designed a new development project where fruits are grown organically in the intra-tambon villages and processed into fruit chips. In 2001 this business plan was submitted to the government as the plan for the One Tambon One Product (OTOP) that the Thaksin administration was promoting (Note 5). The plan was then approved by the government and 1 million Baht (approximately US\$ 25,000 as of 2001) was provided for the project. With that subsidy, the building of a factory to process organically grown fruits into chips was completed in 2003. The project commenced in early 2004. Sixty-nine farm households out of the participating 10 villages engaged in the production of 6 fruit crops including banana, mango, orange, longan, pomelo, and tamarind on the total land of approximately 160 ha within the tambon, using bio-natural pesticides and organic fertilizer called Bokashi (Note 6). As the board of the project, the tambon committee made up of the chairman of the tambon and its staffs, as well as two representatives from each village, established the rules and guidelines related to the production, processing, and sale of organic produce. In addition, the committee gave guidance and supervision to the growers so that they would comply 
with the rules and guidelines and that they would use neither synthetic pesticides nor chemical fertilizer (Amekawa, 2010).

The business got derailed shortly after the project began in 2005, however. Aiming at the third term of chairmanship in the tambon election, the chairman was defeated by a businessman who is from another tambon and has engaged in the oil trading industry (Note 7). The new chairman and his new staffs abolished the organic farming project. Instead, they began to promote policies with a focus on developing public infrastructure within the tambon as he had pledged during the election period. A background of their decision to cancel the organic farming project was that even before the new tambon committee was in place, the factory machine to process fruits into chips did not have enough production efficiency to convert the balance of payments from deficit to surplus (Amekawa, 2010).

As seen, the organic farming project that was established as a small civic sector initiative was terminated by way of an interlinked transition amidst the raging waves of urbanization and democratization. It is ironic that the decentralization to empower the local area ended up responding to the public opinion in favor of creating tangible economic vibrancy rather than developing conservation initiatives for long-term sustainability merits.

\subsection{Good Agricultural Practices}

The public GAP scheme promoted by Thai government was launched in 2004 as the second public GAP program after Malaysia's GAP program that was commenced in 2002. It is called Q-GAP (Q refers to 'quality'), and it has been the largest public GAP program in the world in terms of the amount of certification, with as many as about 120,000 farms, mostly small-scale, who maintained a Q-GAP certified status in 2015 (Table 2). The crude scale of certification is comparable with GlobalGAP which has wielded a strong influence over global food safety standardization. Compared with the number of certifications $(220,000)$ held in 2012, however, it rapidly decreased in the following three years as the country introduced a more stringent new code of practice (the version TAS 9001-2013), which has made it more difficult for applicant farms to get a Q-GAP certification (Note 8). The amount of farms in certified status in the other listed ASEAN countries is much lesser, respectively, which is in part due to the different levels of stringency in compliance for certification. By way of illustrating the gap in the level of stringency in compliance, Malaysian MyGAP requires 100\% of compliance for 29 control points and $90 \%$ of compliance for 77 control points out of the total of 163 control points (the rest being 'encouraged points') (Department of Agriculture, Malaysia, 2005). Meanwhile, the most updated code of conduct of Q-GAP (TAS 9001-2013) requires $100 \%$ of compliance for 23 control points and $60 \%$ of compliance for 41 control points (the rest being 'recommended points') out the total of 116 control points (ACFS, Thailand, 2013). The significantly large amount of farms maintaining a Q-GAP certification in a single country like Thailand would be assisted by its conditions for certification where the required level of compliance in production management for a total of 128 types of target crops is much lower than GlobalGAP and other GAP schemes following it.

Table 2. Public GAP standards in Southeast Asia and Global GAP for crop certification

\begin{tabular}{lllll}
\hline Country/region & Program & $\begin{array}{l}\text { Year of } \\
\text { Inception }\end{array}$ & $\begin{array}{l}\text { Number of Farms Who } \\
\text { Maintain Certified Status } \\
\text { (Year) }\end{array}$ & $\begin{array}{l}112,576(2011) \\
\text { Responsible Agency }\end{array}$ \\
\hline Europe & GlobalGAP & 1999 & EurepEuro-Retailers Produce Working Group \\
Malaysia & MyGAP & 2002 & $903(2015)$ & Department of Agriculture \\
Thailand & Q-GAP & 2004 & $>120,000(2015)$ & Ministry of Agriculture and Cooperative \\
Singapore & SingaporeGAP-VF & 2004 & $7(2013)$ & Agri-Food \& Veterinary Authority \\
The Philippines & PhilGAP & 2005 & $15(2013)$ & Department of Agriculture \\
Viet Nam & VietGAP & 2008 & $575(2013)$ & Ministry of Agriculture and Rural Development \\
Brunei & BruneiGAP & 2013 & $1(2014)$ & Ministry of Industry and Primary Resources \\
ASEAN region & AseanGAP & 2015 & 0 & Asean Secretariat \\
\hline
\end{tabular}

Source: author's tabulation through reference to GAP protocols and queries to the implementing agency

In view of the social participation of small-scale family farms, Q-GAP can be said to maintain a high degree of fairness. Viewed from the perspective of the original role of food safety and quality assurance, however, Q-GAP has the following two problems. First, safety risks persist because the level of monitoring remains low with regard to production management, product quality, and certification process. In this regard, Schreinemachers et al. (2012), in comparing 45 Q-GAP certified and 245 uncertified farms for 9 fruit and vegetable crops in Chiang 
Mai City, showed no significant differences in pesticide use and handling $(p>0.1)$. The study also pointed to a lack of thoroughness in auditing whose time was spent as short as 5 minutes. In examining 64 Q-GAP certified pomelo producers in Chaiyaphum Province, Amekawa (2013) found that approximately half of them did not understand the basic concept of Q-GAP. In addition, most of the reduction of pesticide use around the time of obtaining the first certification was, according to the certified farmers, related to the growth stage of pomelo trees rather than improved practices through Q-GAP training.

The second problem is that a Q-GAP certification is either unacknowledged or unneeded in the market due to a lack of trust in the market on the level of its quality assurance. This problem broadly comprises the following two patterns. The first is the case that buyers do not have interests in the certified product because the existing level of certification is too low to meet the high the expectations of overseas buyers who have a high consumer consciousness of food quality. In this case, consumers and distributers at the overseas market with a high consumer awareness of food quality are skeptical of the level of Q-GAP-based production management for imported products. The second pattern relates to the domestic market where the awareness of safety and expectations for quality assurance tends to be low, so that the presence or absence of certification may not become a problem. In such cases, the product quality sought by consumers is restricted to product appearance and taste. Accordingly, products are bought with no clear recognition nor understanding of a certification given to them at the upstream stage of distribution and sold downstream without a certification label on the product. Even though producers and products receive a certification, traceability and market signals hardly function. Hence, Q-GAP standard has challenges associated with the effectiveness of its certification in production and distribution due to the comparatively low level of the set standard, calling for a fundamental reform on the compliance level.

\section{Conclusion}

In Thailand, it has been long since the crisis of small-scale family farms began to be expressed on the course where urbanization and industrialization have proceeded along with the commercialization of the economy. Slumping agricultural prices and the transforming rural economy accelerated the abandonment of farming, hence the rapid de-agriculturalization of society occurring during the 20 years from 1980 to 2000. Now the majority of farms are run part-time and the majority of household incomes are derived from off-farm employment. Further, the rural development policies that were promoted after the inauguration of Thaksin administration for the purpose of stimulating the domestic demand have been taken over by the succeeding administrations after Thaksin's downfall. Yet unseen are signs of economic disparities shrinking between the capital and provinces as well as between cities and the rural countryside.

With a consideration of the characteristics of small-scale family agriculture in Thailand, this paper has shed light on the cohort of Thai society that seeks to pin hopes on sustainable agriculture for the improvements of small-scale farmer livelihoods and environmental conservation. Many attempts aimed at promoting organic farming in Thailand have ended up as failure, however, and therefore the current situation cannot be seen optimistically given the general background of Thai agricultural development involving ecosystem degradation, flagging agricultural prices, insufficient external support, chronic labor shortage, among others. As seen in the case study, democratization may work against the attempt of sustainable agriculture in the existing structure of the rural economy. Further, Q-GAP standard as a public food safety assurance system has exhibited contradictions between the goal of supporting the bulk of small-scale family farms in rural Thailand and the objective of ensuring the level of compliance being commensurate with the demand in the export market.

Late Atsushi Kitahara, who was a leading authority of studies on Thai rural society, stated bluntly that alternative agriculture such as natural farming, organic farming, and integrated farming, "is not ably performed by poor farmers but only by middle- and upper-class farmers who have sufficient farmland and with good off-farm incomes" (Kitahara, 2002, p. 118). He also argued that farmers engaging in the development of the market for such types of agriculture and related negotiations "are neither average farmers nor from average village communities but a select few farmers and their associations who have excellent skills and a strong faith" (ibid.). While the reality may not be as simple as Kitahara argued, it cannot be denied that there is some truth in the remarks. In the meantime, a close look at farming practices in rural Northeast Thailand informs that many farmers are trying to sustainably secure yields by combining various alternative farming practices while controlling the cost of agrochemicals. The perseverance and wisdom of the farmers and the trainers from the extension office are of impressive quality. While seemingly not very spectacular, such attempts realistically support the basis of small-scale family farming, thus garnering more attention to efforts to consider the future sustainability of agriculture and livelihoods associated with small-scale family farms in rural Thailand. 


\section{References}

Amekawa, Y. (2010). Rethinking sustainable agriculture in Thailand: A governance perspective. Journal of Sustainable Agriculture, 34, 389-416. http://dx.doi.org/10.1080/10440041003680254

Amekawa, Y. (2013). Can a public GAP approach ensure safety and fairness? A comparative study of Q-GAP in Thailand. The Journal of Peasant Studies, 40(1), 189-217. http://dx.doi.org/10.1080/03066150.2012.746958

Buch-Hansen, M. (2001). Is sustainable agriculture in Thailand feasible? Journal of Sustainable Agriculture, 18, 137-160. http://dx.doi.org/10.1300/J064v18n02_11

Calcaterra, E. (2013). Defining smallholders: Suggestions for an RSB smallholder definitions. Retrieved from http://energycenter.epfl.ch/files/content/sites/energycenter/files/projets/Bioenergy $\% 20 \mathrm{Team} / \mathrm{Defining} \% 20 \mathrm{~s}$ mallholders_v30102013.pdf

Department of Agriculture, Malaysia. (2005). Malaysian farm certification scheme for good agricultural practice (SALM) standard. Retrieved from https://law.resource.org/pub/my/ibr/ms.gap.2005.pdf

Green Net. (2015). Green Net homepage. Retrieved from http://www.greennet.or.th/en

Gallagher, K., Ooi, P., Mew, T., Borromeo, E., Kenmore, P., \& Ketalaar, J.-W. (2005). Ecological basis for low-toxicity integrated pest management (IPM) in rice and vegetables. In J. Pretty (Ed.), The pesticide detox: Toward a more sustainable agriculture (pp. 116-134). http://dx.doi.org/10.1108/ijshe.2005.24906 cae. 008

Hirokawa, S. (2010). Case studies of rural development and clean agriculture in Lao PDR. The Third International Conference on Lao Studies, Khon Kaen University, 14-16 July, 2010. Retrieved from http://www.aessweb.com/pdf-files/4-241-AJARD,\%20Vol.\%203(7)2013-457-468.pdf

Inoue, S. (2012). dai 1 shō. kantorī repōto: tai-seiji hendō to kome seisaku [Chapter 1. Country report: Thailand - Political change and rice policy]. Agriculture, Forestry and Fisheries Policy Institute, Research Document for Special Study (Major countries) (2), 1-34. [Japanese]

Inoue, S. (2010). dai 2 shō. kantorī repōto: tai [Chapter 2. Country report: Thailand]. Agriculture, Forestry and Fisheries Policy Institute, Research Document for Special Study (Bilateral) 13, 43-86. [Japanese]

Jitsanguan, T. (2001). Sustainable agricultural systems for small-scale farmers in Thailand: Implications for the environment. Retrieved from http://en.fftc.org.tw/htmlarea_file/library/20110718190247/eb509.pdf

Kan'no, T. (2008). tai ni okeru yūki nōgyō no genjō to kadai [The current situation and challenges of organic farming in Thailand]. Self-directed project. [Japanese]

Kasem S., \& Thapa G. B. (2012). Sustainable development policies and achievements in the context of the agricultural sector in Thailand. Sustainable Development, 20, 98-114. http://dx.doi.org/10.1002/sd.467

Kitahara J. (1985). kaihatsu to nōgyō-tōnan ajia no shihonshugika [Development and agriculture: The capitalization of Southeast Asia]. Kyoto: sekai shisō-sha. [Japanese]

Kitahara, J. (2002). nōson shakai no kako to gendai no henka [The past and contemporary changes of rural society]. In J. Kitahara (Ed.), hendō no higashi ajia shakai [Changing East Asian society]. Tokyo: aoki shoten. [Japanese]

Kitahara, J. (2005). tai nōson no shakai keizaiteki hendō katei-fïrudo chōsa monogurafu seiri no kokoromi [The process of socio-economic changes in rural Thailand: An attempt to organize field research monographs]. Economic Science, 52(4), 17-33. [Japanese]

Maruyama, K. (1996). gendai tai nōmin seikatsushi-tai bunka wo sasaeru hitobito no kurashi [A life ethnography of contemporary Thai farmers: The life of people who support Thai culture]. Fukuoka: Kyushu daigaku shuppankai. [Japanese]

Mizuno, K. (1981). tai nōson no shakai soshiki [The social organization of rural Thailand]. Tokyo: sōbunsha. [Japanese]

Mori'izumi, Y., Piyawan, S., Hondō, Y., \& Waki, Y. (2008). tai ni okeru jizokuteki nōgyō-baio etanōru seisan no jizokusei hyōka [Sustainable agriculture in Thailand: An assessment of the sustainability of ethanol production]. Academic Frontier Promotion Project: The Integrated Research for the Development and Operation of the Regional Strategic Vision of Digital Asia, 1-20. [Japanese]

National Economic and Social Development Board (NESDB). (1997). The 8th national economic and social development plan 1997-2001. Bangkok: Office of the Prime Minister. 
National Bureau of Agricultural Commodity and Food Standards (ACFS). (2013). Thai agricultural standard TAS 9001-2013: Good agricultural practices for food crop. Retrieved from http://www.acfs.go.th/standard/download/eng/GAP_Food_Crop.pdf

Oda, T. (2009). tai ni okeru 'taru wo shiru keizai' shisō ni nezashita nōson kaihatsu jigyō [Rural development projects rooted in the thought of 'sufficiency economy' in Thailand]. Civil Engineering Consultant, 242, 44-47. [Japanese]

Ōuchi, M. (2007). tai ni okeru nōson kaihatsu to NGO no yakuwari [Rural development in Thailand and the role of NGOs]. In Y. Kubota (Ed.), ajia nōson hatten no tenbō-taitō suru yonkakoku [Challenges of rural development in Asia: The rising four countries]. Tokyo: chikuba shobō. [Japanese]

Phongphit, S. (1992). mura wa jiritsu dekiru-tōhoku tai no rōnō (K. Nonaka, Trans.) [The village can be self-reliant: An old man in Northeast Thailand]. Kagoshima: sansan-sha. [Japanese]

Röling, N., \& van de Fliert, E. (1994). Transforming extension for sustainable agriculture: The case of integrated pest management in rice in Indonesia. Agriculture and Human Values, 11(2), 96-108. http://dx.doi.org/10.1007/BF01530451

Satomi, M. (2009). tai ni okeru chīki saisei undō ni manabu—'aguroforesutorī’ eno tenkan to 'jisedai eno keishō' ni chakumoku shite [Learning from the local revitalization movement in Thailand: A focus on the 'conversion to agro-forestry' and 'inheritance to the next generation']. Tokyo: nōson gyoson bunka kyōkai. [Japanese]

Schreinemachers, P., Schad, I., Tipraqsa, P. Williams, P. M., Neef, A., Riwthong, S., Sangchan, W., \& Grovermann, C. (2012). Can public GAP standards reduce agricultural pesticide use? The case of fruit and vegetable farming in Northern Thailand. Agriculture and Human Values, 29, 519-529. http://dx.doi.org/10.1007/s10460-012-9378-6

Schreinemachers, P., Afari-Sefa, V., Heng, C. H., Dung, P. Y. M., Praneetvatakul, S., \& Srinivasan, R. (2015). Safe and sustainable crop protection in Southeast Asia: Status, challenges and policy options. Environmental Science \& Policy, 54, 357-366. http://dx.doi.org/10.1016/j.envsci.2015.07.017

Suehiro, A. (2009). tai-chūshinkoku no mosaku [Thailand: The quest of a semi-developed country]. Tokyo: iwanami shoten. [Japanese]

Suksuri P., Mori'izumi, Y., Hondo, H., \& Wake, Y. (2008). Sustainable agriculture in Thailand: An evaluation on the sustainability of ethanol production. Digital Asia Regional Study Research Center. Retrieved from http://www.hondo.ynu.ac.jp/hiroki/sustainable_agriculture_E.pdf

Takeuchi, T. (2015). tai kazoku no kōzō saikō [The reconsideration of the structure of Thai family]. Ritsumeikan International Studies, 27, 1085-1107. [Japanese]

(2012). tōhoku tai ni okeru inasaku keiei no henka [Changes in rice farm management in Northeast Thailand]. Ritsumeikan International Studies, 25, 367-385. [Japanese]

(2010). tai no shakai hendō to tōhoku chihō jūmin no taī̄ [Social change in Thailand and responses of the residents in the Northeastern region]. Ritsumeikan International Studies, 58, 902-926. [Japanese]

(2009). bān to kazoku—tai kazoku no kisō wo motomete [Baan and family: Seeking the substratum of Thai family]. Ritsumeikan International Studies, 21, 551-574. [Japanese]

Tsumura, F. (2014). 'taru wo shiru keizai' to 'takushinomikusu' no aida—kakeibo chōsa kara miru tōhokutai no nōson keizai [The breach between 'Sufficiency Economy' and 'Thaksinomics': The rural economy of Northeast Thailand in view of household accounting survey]. Fukui Prefectural University, 42, 27-44. [Japanese]

Panyakul, V. (2001). Organic agriculture in Thailand. A National Report Prepared for ESCAP. In Exploring the potential of organic farming for rural employment and income generation in Asia. Bangkok: ESCAP.

Panyakul, V. (n. d.). Thailand's organic 2011. Green Net - Earth Net [Power Point slides]. Retrieved http://unctad.org/meetings/en/SessionalDocuments/DITC_TED_OA1212LOAF_Thailand.pdf

Watanabe, A. (2008). shigen wa doko ni arunoka-tōhoku tai ugoku hitobito no mura de [Where is a resource? At a village in Northeast Thailand where people move]. In J. Sato (Ed.), shigen wo miru me-genba kara no bunpai ron [The eyes to watch over the resource: The theory of distribution from the field] (pp. 35-58). Tokyo: tōshin dō. [Japanese] 
Wongkul, P. (1993). mura no shū niwa kariga aru—hōtoku no kaihatsusō tachi (K. Nonaka, Trans.) [I owe to the villagers: The moral requital development monks]. Kagoshima: sansan sha. [Japanese]

\section{Notes}

Note 1 . The number of pesticide poisoning incidents was 74 in 1971. In ten years, it soared rapidly to 2,170 in 1981 (Kan'no, 2008).

Note 2. Sufficiency Economy is called 'Setakit Po Pian' in Thai. The King spoke of the concept in his birthday speech in 1997, which drew a great deal of attention. In fact, the King had advocated this philosophy since 1969 (Inoue, 2012).

Note 3. In this project, the Royal Development Study Center stationed in every region works in concert with local agricultural extension stations of the Ministry of Agriculture and Cooperatives. They promote the dissemination of knowledge and technical training that are deemed necessary for farming practices, as well as the distribution of seedlings of fruit trees, perennial woods, and cultured fish for aquaculture. According to a survey conducted in 2004 of 100 households participating in the project, 76 percent responded that they could work on the farm using the water exclusively from the pond, and that 98 percent gained over 10 times more income than when they had no ponds yet (Mori'izumi et al., 2008).

Note 4. This organic vegetable project ended in 2004, replaced by a new project to directly send to and sell organically grown bananas at the markets in the provincial capital of Chaiyaphum. The reasons for this transition were: (1) consumers in Bangkok were dissatisfied with the amount of production in the dry season, in particular March and April; (2) hypermarkets in Bangkok began to sell organic vegetables to which consumers in Bangkok shifted their patterns of purchase and consumption; (3) there was a prospect that with only little care to be taken, selling organic bananas locally would result in more profits than selling organic vegetables to expatriates in Bangkok.

Note 5. This policy was designed and implemented in Thaksin administration by modeling after the One Village One Product program in Ōita prefecture, Japan. It was introduced to promote local entrepreneurship in rural communities so that quality local products can be produced, branded, and sold at local, national, and international levels. After the military coup d'etat ousted Thaksin and overthrew his administration in 2006, the OTOP was revoked once yet revived with minor changes as Local and Community Products.

Note 6. Bokashi is the name of traditional compost in Japan. Here it refers to the mixture of the faces of livestock such as cattle, hogs, and fowls, the chaff of rice and wheat, liquefied sugarcane, water, and EM ('effective microorganism' disseminated by the Japanese religious group called "Japan Kyūsei-kyō," made up of fruits and vegetables fermented with water, alcohol, and sugar, etc.).

Note 7. The chairman lost the election to the rival candidate with the voting result of 2,002 versus 1,874 .

Note 8. The version TAS 9001-2013 has made it more difficult for applicants to get a Q-GAP certification than the initial version introduced in 2004 mainly in the following three ways: (1) the level of compliance became higher than the previous requirements of $51 \%$ compliance in each of the 8 categories of the 81 total control points for the 2004 version and the 69 total control points for the 2009 version (TAS 9001-2009) of the code of practice; (2) holding a land title for the land on which the cultivation of a particular crop is related to the application for Q-GAP became mandatory; and (3) compliance with record keeping became mandatory.

\section{Copyrights}

Copyright for this article is retained by the author(s), with first publication rights granted to the journal.

This is an open-access article distributed under the terms and conditions of the Creative Commons Attribution license (http://creativecommons.org/licenses/by/3.0/). 